\title{
Assessment of Indoor Environmental Quality (IEQ): Students Well-Being in University Classroom with the Application of Landscaping
}

\author{
Nurul Malina Jamaludina, Norhayati Mahyuddin and Farid Wajdi Akashah \\ Centre for Construction, Building and Urban Studies (CeBUS), Department of BuildingSurveying, University of Malaya, 50603 Kuala Lumpur \\ Malaysia
}

\begin{abstract}
The environmental quality (IEQ) in a building is an important element to perceive the good health and comfort level for the building occupants. However, each building contributes different environmental quality results towards the indoor spaces and the occupants. Learning environment is one of the spaces that need attention as it is related to student's well being as well as their learning performance. Existing knowledge on IEQ is still limited concerning the desirable levels of air quality, maintenance, and other factors affecting IEQ in Malaysian educational establishment. Therefore, the study of indoor environment quality in buildings has been carried out in educational building as it acts as important place in learning process. The methodologies used to conduct this research are divided into two methods, which are classroom measurement normal condition and classroom intervention setting. This is done in order to compare and monitor the improvement of environment in the classroom. This research focuses on the comparison of IEQ in different classroom environment setting and the student satisfaction level in their normal classroom environment. Measurement of temperature $\left({ }^{\circ} \mathrm{C}\right)$, relative humidity, carbon dioxide $\left(\mathrm{CO}_{2}\right)$, Volatile Organic Compound (VOC), dust particles (PM10), lighting (lux), and noise (decibel) in the classroom were collected and questionnaires were distributed among the students. This research found that most of the elements in the classroom was incompliance with the standard threshold limit value. The level of VOC in the classroom was noted to be significantly high $(11.7 \mathrm{ppm})$ compared to the standard threshold limit. An intervention on the normal condition classroom was set up with selected plant placed in the classroom. Results show a tremendous reduction in the percentage of relative humidity, level of TVOC, as well as $\mathrm{CO}_{2}$.
\end{abstract}

\section{Introduction}

There are many researchers found that IEQ may affects peoples performance. This is proven by the study of (Fisk, 2000; Mendell et al., 2002) which explained that poor indoor environments could affect the student learning process in school. According to National Institute of Occupational Safety \& Health, Indoor environmental quality (IEQ) is defined as the buildings environment quality which related to health and wellbeing of those who occupy space in it (NIOSH, 2013). According to (Hill MC, 2009), a satisfactory condition of environment such as lighting, temperature, and space management plays an important role in order to improved student satisfaction towards learning environments.

Based on latest data provided from The Ministry of Higher Education (MOHE) in Malaysia which is around 10 years ago, there are more than 900,000 students pursuing higher education in 20 public universities, 33 private universities and university colleges, 4 foreign university branch campuses, 22 polytechnics, 37 community colleges and about 500 private colleges (The Ministry of Higher Education (MOHE), 2004). While for

\footnotetext{
a Corresponding author: malina_nurul@siswa.um.edu.my
}

the total number of government schools in Malaysia including primary schools and secondary schools are 10,119 employing over 421,393 teachers with 5138682 number of students in Malaysia (MOE, 2014). From this, we can classrooms than any other environment of schools, therefore the IEQ of the classroom need to be concern in order to improve their academic achievement.

There are many factors of IEQ that may affect to the student. This is because each building will have different environmental quality that will be perceived by the occupants that would relate to the types of activities carried out in indoor spaces of the building i.e., classroom, laboratories and others. Since Malaysia's climate is classified as 3 equatorial, being hot and humid throughout the year, this might result in dissatisfaction of the building occupants regarding to IEQ issues of building, with particular emphasis on thermal comfort.

The study by (K. Khadijah et al.2013), has been carried out in classroom on second floor at local school in Bandar Baru, Selangor in order to assess thermal condition during teaching lesson. This study was carried out throughout 5 days from $2 \mathrm{pm}$ to $6 \mathrm{pm}$. As a result, both student and teacher are not satisfied with the environment quality in their classroom. This is due to lack of air 
ventilation in the classroom. Besides that, the layout plan of class need to be changed as the position of students table near from each other which will lead to discomfort to student. This is because every of human body provides heat transfer. Therefore, if they seat to close to each other they may feel discomfort because of high thermal comfort.

However, the problem in Malaysia is the occupants of the building are not aware of the effects of IEQ in their surrounding especially in the learning environment. Existing knowledge is still limited concerning the desirable levels of air quality, maintenance, and other factors affecting IEQ in Malaysian educational establishments. According to (Turunen et al., 2014) poor IEQ can lead to health symptoms it can also cause decreased student focusing in the classrooms. Findings show correlation between headaches, dizziness, heavy head, tired, difficulties concentrating, unpleasant odor, and high $\mathrm{CO} 2$ concentrations are example of health symptoms that felt by the students due to poor environment quality. This can be preventing by using plant as to decrease the effect of IEQ especially for indoor air pollutants. However, according to (Wood et al. 2006) the studies on ability of potted-plants reducing airborne contaminants in improving the air quality are still limited.

Other than that, ASHRAE, (2008) described that better IEQ can help and improve the learning process of students. Based on the basic space and function of educational buildings, where teaching and learning are the priority, it is predicted that universities may also be facing similar problems with the IEQ in their classrooms. One of the primary reasons for this is that occupancy is generally denser in classrooms. Therefore, this research is conducted to study the occupants ${ }^{\text {ee }}$ perception on how different environment gives different impacts on their method.

\section{Materials and Methods}

This research was conducted by using quantitative analysis applying field work monitoring conducted at every designated area where information of indoor environmental quality is measured as listed in Table 1.

Table 1: Research Methods

\begin{tabular}{|l|l|l|l|}
\hline Method & $\begin{array}{l}\text { Questionnaire } \\
\text { Survey }\end{array}$ & \multicolumn{2}{|c|}{ Fieldwork Monitoring } \\
\cline { 2 - 4 } & $\begin{array}{l}\text { Measurement } \\
\text { Set Up }\end{array}$ & $\begin{array}{l}\text { Classroom } \\
\text { Intervention }\end{array}$ \\
\hline Details & $\begin{array}{l}\text { Questionnaire } \\
\text { (based on } \\
\text { elements of } \\
\text { IEQ } \\
\text { current } \\
\text { students } \\
\text { satisfaction } \\
\text { level }\end{array}$ & $\begin{array}{l}\text { Sampling } \\
\text { devices used } \\
\text { to monitor the } \\
\text { indoor } \\
\text { environment } \\
\text { of } \\
\text { classroom the }\end{array}$ & $\begin{array}{l}\text { Intervention } \\
\text { on } \\
\text { application } \\
\text { of landscape } \\
\text { to reduce the } \\
\text { level of } \\
\text { TVOC in the } \\
\text { classroom. }\end{array}$ \\
\hline
\end{tabular}

\subsection{Questionnaire survey}

20 questionnaires were distributed among the students in the classroom to investigate the satisfaction level of the students in the classroom. The questionnaire mainly related to IAQ, acoustic quality, visual comfort, thermal comfort and effect of IEQ to the students learning performance. All data collected from the questionnaire survey will be analyzed with a statistical method using Microsoft Excel.

\subsection{Fieldwork monitoring}

Measurement will focus on temperature, ventilation and relative humidity in the selected area which is might be considered as factor that can contribute to poor indoor air quality. There are 2 types of measurement, which is classroom measurement set up in Fig. 1 and intervention on the classroom environment in Fig. 2.

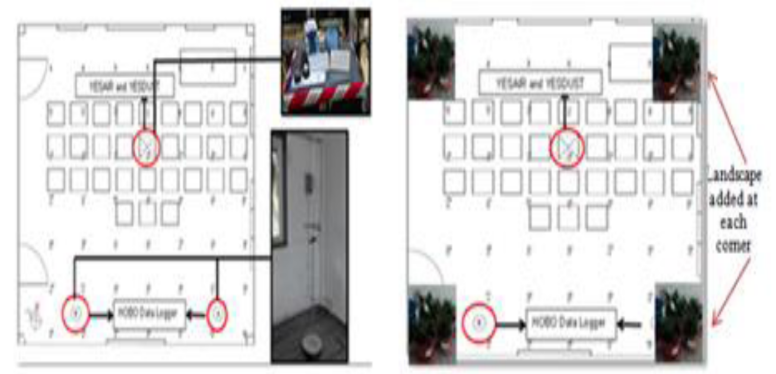

Figure 1: Classroom measurement set up

Figure 2: Intervention on the classroom environment

\subsection{Classroom Environment Intervention}

The environment interventions will be designed to compare between the level of IEQ based on the current IEQ level in the classroom and by placing plants inside the classroom. This is because, from the data collection, shows that the rate of TVOC inside the classroom was significantly high which exceeded the standard threshold limit value (TLV). Therefore, Peace lily and Janet Craig species were selected and placed in each corner of the classroom.

\section{Results and Discussions}

\subsection{Questionnaire Analysis}

Fig. 3 shows that the classroom was fully occupied by students from 1-3 hours daily. Normal class session starts from 9.00 am daily and finish at $5.00 \mathrm{pm}$. However, due to the varying time table schedule, most of the students spend less time in the classroom. 


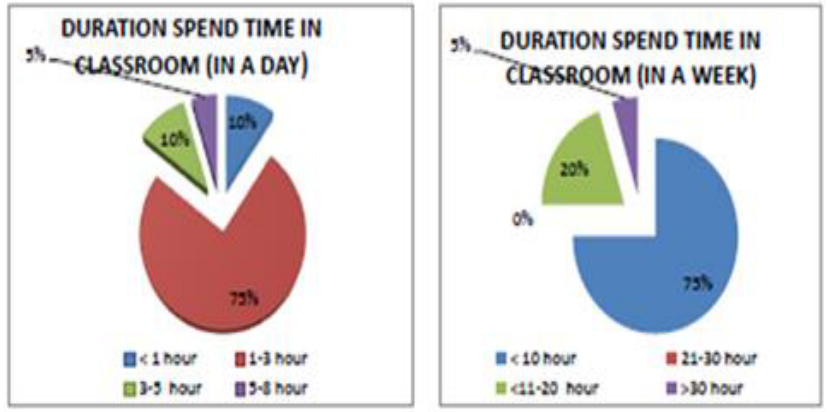

Figure 3: Daily and Weekly time duration spent in the classroom

Feedback from the questionnaires justified that the occupant's perceived learning productivity is not easily interfered by any of the elements of indoor environment quality probably due to the young age of students. From the questionnaire, the mean age of the respondents is around 19 years old. This explains that the respondents are neither easily being affected by indoor environmental qualities and nor susceptible to any health symptoms. Moreover, all possible health symptoms were found unnoticeable in the classroom (see Fig. 4). However, there were some minor health symptoms that has been identified such as stress, dry skin, itchy eye, blurred vision as well as tired eye.

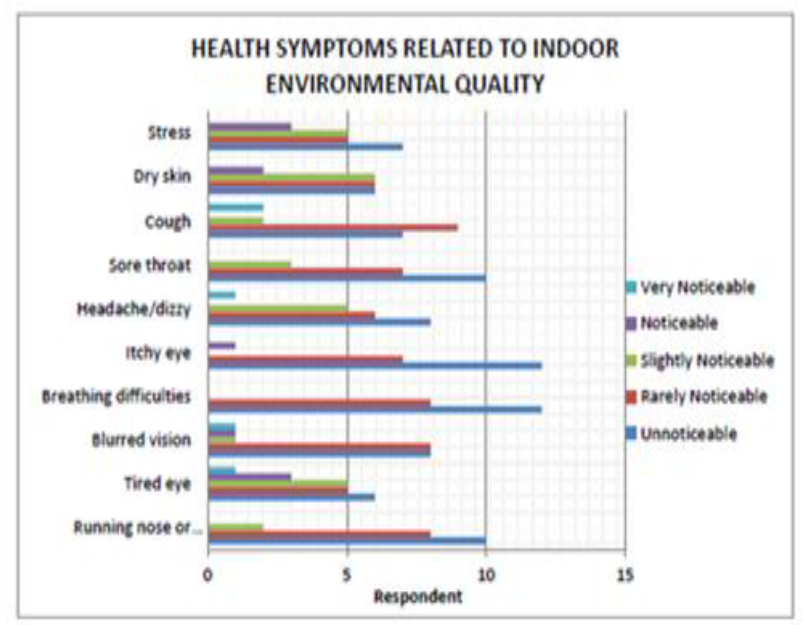

Figure 4: Health Symptoms Related to IEQ

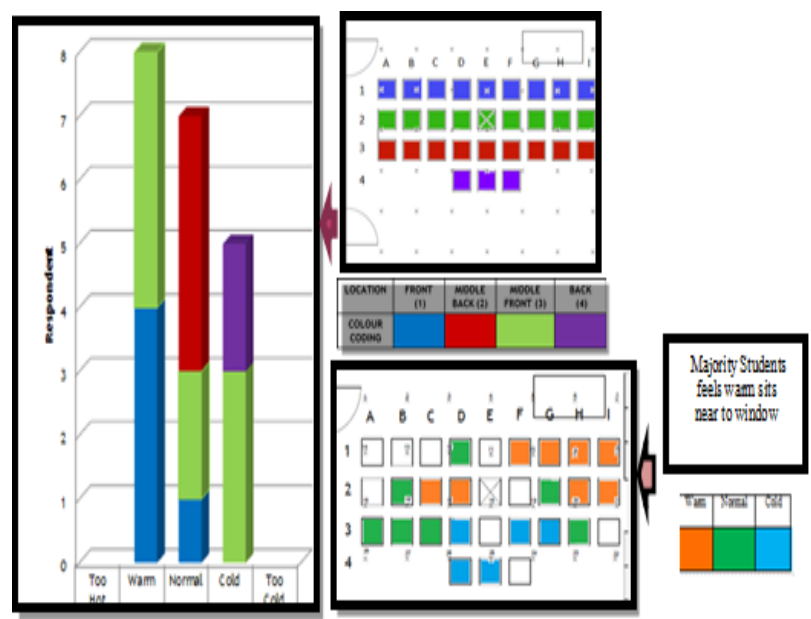

Figure 5: Students satisfaction level on the thermal condition
With regards to the thermal condition in the classroom, majority of the students rated warm as illustrated in Fig. 5. This might be due to the heat transmission through the windows and lack of air circulation, which eventually reduces the ventilation rates in the classroom. It was observed that the classroom orientation with windows is towards Easts, which mean that the classroom gain higher penetration from sunlight and this can cause heat gain in the classroom. However, there were few students rated cold in the classroom. Based on the sitting position (colour indicator in Figure 5 ), it can be concluded that the students perceived satisfaction on the thermal condition is due to the location in the classroom whether or not they are sitting near the air conditioner. In addition to this, it was also observed that only one air conditioner was operated in the classroom. Hence, the perceived satisfaction level on the thermal comfort was not satisfactory.

\subsection{Fieldwork Monitoring -Thermal Comfort, Ventilation and Indoor Air Quality}

The measurement taken in the classroom is to identify the element of indoor air quality that contribute into environment quality in the classroom which include temperature, relative humidity, volatile organic compound (VOC) and concentration of carbon dioxide $\left(\mathrm{CO}_{2}\right)$. Fig. 6 shows data collected on measurement of indoor temperature at BT7. The temperature was compared with ASHRAE, 2010 Standard as well as Industrial Code of Practice (2010). The ASHRAE provide the suitable temperature for good indoor air quality is within $23^{\circ} \mathrm{C}$ to $26^{\circ} \mathrm{C}$.

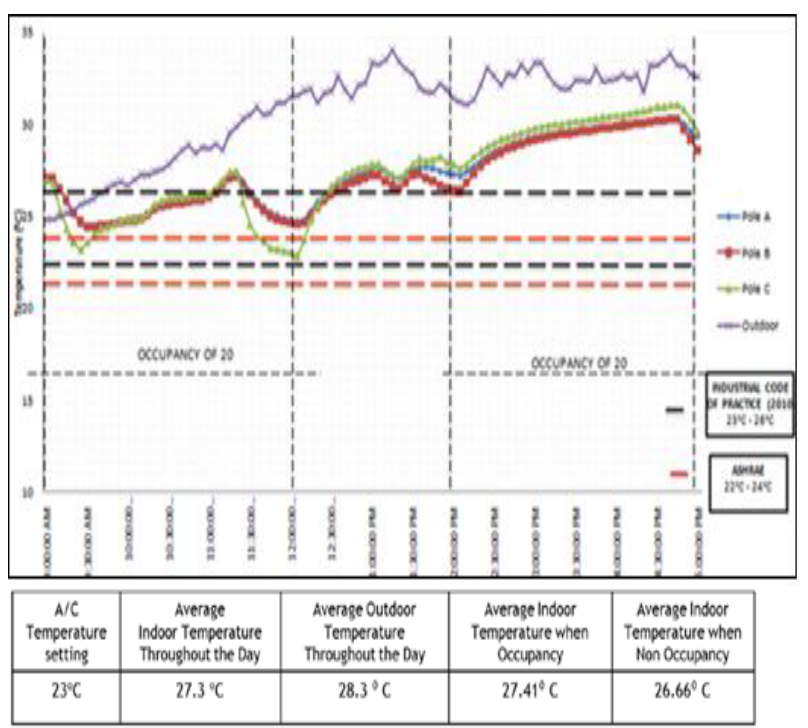

Figure 6: Indoor air temperature in the classroom at normal condition

Based on the graph, the indoor air temperature in the classroom is in the range of $23^{\circ} \mathrm{C}$ to $30.9^{\circ} \mathrm{C}$. This result supported the findings from the questionnaire where majority of the students feeling warm in the classroom (see Fig. 5). The indoor air temperature pattern was observed to be influence by the outdoor air temperature. 
However, it was noted that from 9.00 am to $2.00 \mathrm{pm}$, the ratio of indoor outdoor temperature was slightly lower. This is due to the operation of $t$ air conditioning system when students occupy the classroom. Yet the temperature levels were above the standard range set by ASHRAE and Industrial Code of Practice (dotted lines) as illustrated in Fig. 6.

With regards to the air circulation in the classroom, it was noted that the average reading for air velocity was only $0.14 \mathrm{~m} / \mathrm{s}$ as illustrated in Fig. 7. This value is below the TLV set by World Health Organization (WHO). Air velocity level that is below which is $0.25 \mathrm{~m} / \mathrm{s}$ is considered as stale air. Due to this, it can be concluded that the air movement in the classroom is very low. This finding is supported further by the students' perceived satisfaction level on the air movement based on the responses from the questionnaire.

Majority of the students feel that the condition of the air in the classroom are quite stuffy. This is probably due to the enclosed classroom where doors and windows were closed at most of the time when the room is occupied. It is also due to the operation of only one air conditioning system, which reduces the ventilation rates of the classroom further. It was observed that there were two exhaust fan above the door, but was not functioning to allow the air exchange of air.

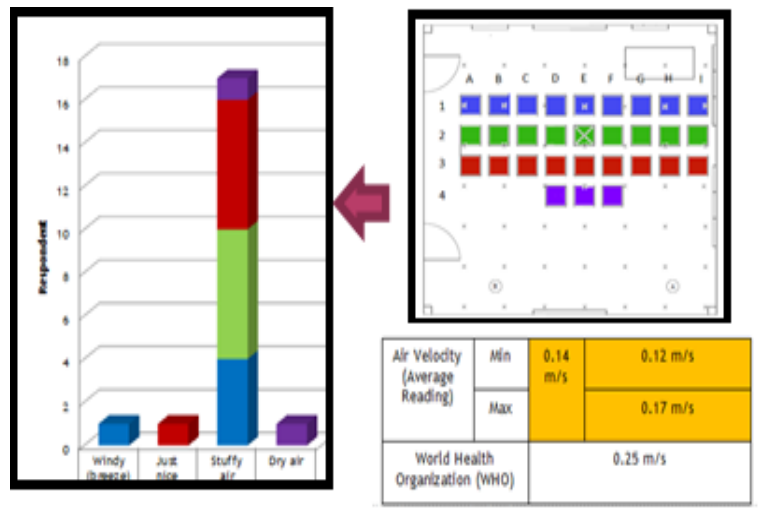

Figure 7: Perceived Satisfaction on the air movement in the classroom

Fig. 8 on the other hand shows data collected on measurement of relative humidity in the classroom. From the graph, it shows that the relative humidity in the classroom is in the range of $53.12 \%$ to $78.2 \%$. At certain time of the day, the RH level was noted to go beyond the TLV (above $60 \%$ set by ASHRAE).

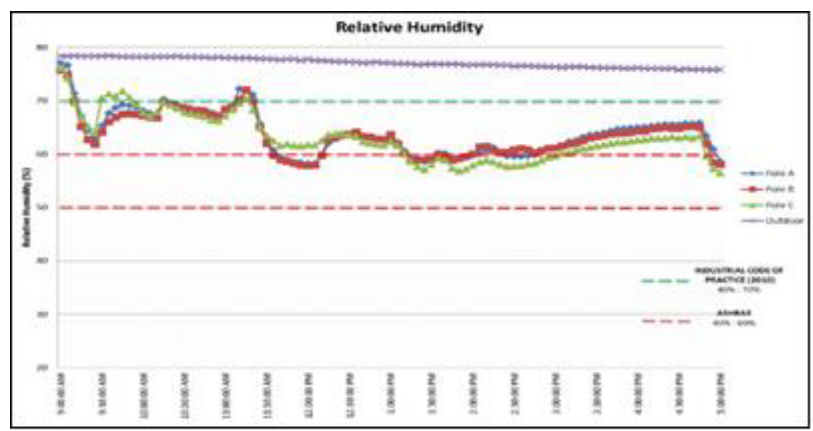

Figure 8: Relative Humidity level in the normal condition classroom
In addition to $\mathrm{RH}, \mathrm{CO}_{2}$ was also measured and it was found that the concentration level of $\mathrm{CO}_{2}$ in the classroom is within the acceptable standards for the $\mathrm{CO}_{2}$ that should be $700 \mathrm{ppm}$ above the outdoor concentration i.e., approximately $1000 \mathrm{ppm}$. Similar to $\mathrm{CO}_{2}$, there was no serious issue regarding dust particle $\left(\mathrm{PM}_{10}\right)$ in the classroom. On the other hand, TVOC concentration on both monitoring days shows a significantly high value beyond the TLV set (3ppm) as illustrated in Fig. 9. The sources of TVOC were probably from cleaning chemicals, which is use by cleaners during break time (1$2 \mathrm{pm}$ ) every day. It can also be from perfumes that were used by the students in the classroom as well as marker pen used by the lecturer during learning process.

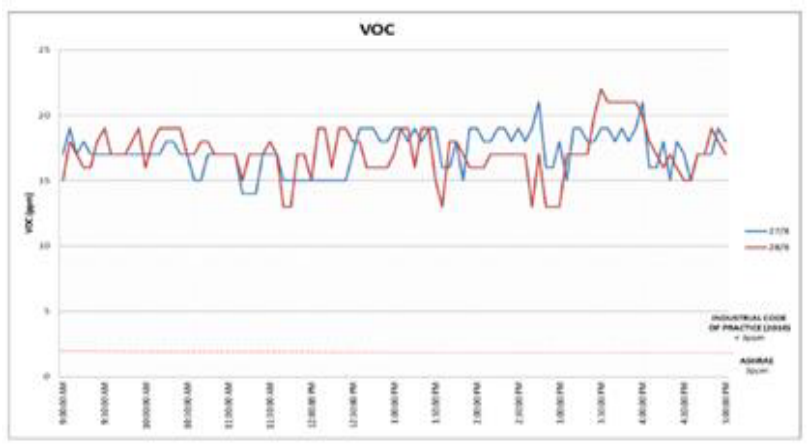

Figure 9: TVOC concentration level in the normal condition classroom

\subsection{Fieldwork Monitoring -Acoustic Quality}

Acoustic quality is referred to as an acceptable range of sound that does not cause any disturbed feeling. Based on the grab sampling taken in the classroom, the sound level was found to be slightly higher which exceeded the TLV of the background sound level $(35 \mathrm{db})$. From the data obtained, average readings for sound level were approximately $59 \mathrm{db}$. This is probably due location of the classroom block which is situated next to the main road and also there is intermittent noise contributed by adjacent areas such as the walkway and generator outside of the classroom as illustrated in Fig. 10.
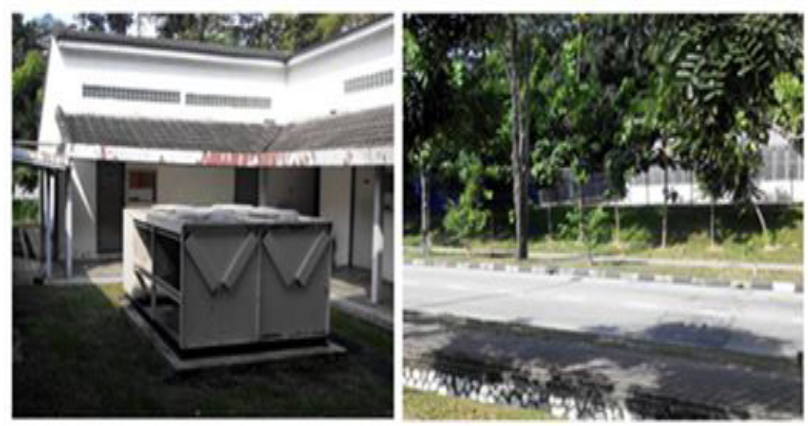

Figure 10: Possible sources of noise 


\subsection{Fieldwork Monitoring -Lighting Quality}

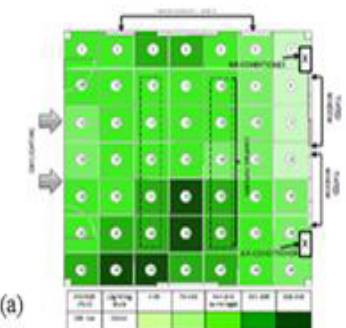

(b)

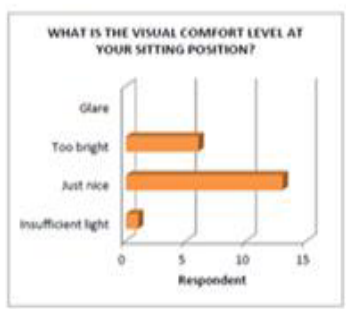

Figure 11: (a) Lighting level in the classroom (b) Students satisfaction level on the lighting quality

In Fig. 11(a), the color coding in grids shows the lighting level that were captured using grab sampling method. The middle of the classroom received higher level of intensity compared to the side of the classroom (near to window). This is because the artificial lighting arrangement was more focus at the middle of the classroom compared to other side. Lower lighting intensity was observed at the right side of the classroom, due to the tinted glass windows, which reduces excessive lighting penetration during sunny day. Overall, most of the areas in the classroom had lighting intensity below the standard lighting level suitable for classroom, which is 300lux. However, based on the responses from the students on the lighting quality (Fig. 11b), majority feels that the lighting quality is just nice with lighting intensity below 300lux.

\subsection{Summary of Normal Condition Classroom}

Table 2: Summary of IEQ Measurements in a Natural Condition Classroom

\begin{tabular}{|c|c|c|c|c|c|}
\hline \multicolumn{2}{|c|}{ Element } & \multicolumn{2}{|c|}{ Average } & TLV (Threshold & Remarks \\
\hline \multirow[t]{2}{*}{ Temperature $\left({ }^{\circ} \mathrm{C}\right)$} & Occupancy & \multirow[t]{2}{*}{$27.3^{\circ} \mathrm{C}$} & $26.17^{\circ} \mathrm{C}$ & \multirow[t]{2}{*}{$22^{\circ} \mathrm{C}-26^{\circ} \mathrm{C}$} & \multirow[t]{2}{*}{ Above TLV } \\
\hline & Non- occupancy & & $26.66^{\circ} \mathrm{C}$ & & \\
\hline \multicolumn{2}{|c|}{ Relative Humidity $(\%)$} & \multicolumn{2}{|c|}{$76.4 \%$} & $40 \%-70 \%$ & Above TLV \\
\hline \multicolumn{2}{|c|}{ VOC $(p p m)$} & \multicolumn{2}{|c|}{$11.7 \mathrm{ppm}$} & ippm & Above ILV \\
\hline \multicolumn{2}{|c|}{ Particulate matter (PM10) } & \multicolumn{2}{|c|}{$0.11 \mathrm{mg} \mathrm{m}^{\mathrm{j}}$} & $0.15 \mathrm{mg} \mathrm{m}^{\mathrm{j}}$ & Compliance \\
\hline \multirow{2}{*}{$\begin{array}{l}\text { Air velocity } \\
\text { (ms) }\end{array}$} & Min & \multirow[t]{2}{*}{$0.1 \mathrm{~mm} / \mathrm{s}$} & $0.12 \mathrm{~m} / \mathrm{s}$ & \multirow[t]{2}{*}{$0.25 \mathrm{~m} / \mathrm{s}$} & \multirow[t]{2}{*}{ Below TLV } \\
\hline & $\operatorname{Max}$ & & $0.17 \mathrm{~m} / \mathrm{s}$ & & \\
\hline \multicolumn{2}{|c|}{ Acoustic (Background) } & \multicolumn{2}{|c|}{$59.5 \mathrm{dBA}$} & $\angle 3 \mathrm{ABA}$ & Above ILV \\
\hline \multicolumn{2}{|c|}{ Lighting (lux) } & \multicolumn{2}{|c|}{ 178.53/ux } & $300 \operatorname{lux}$ & Below TLV \\
\hline
\end{tabular}

Table 2 shows the summary for current condition in the classroom. Most of the elements in the classroom were incompliance with the standard TLV. The level of TVOC in the classroom was significantly high with an average concentration of $11.7 \mathrm{ppm}$ compared to $3 \mathrm{ppm}$ as set in the standard TLV. According to Jim and Chen (2008), one of the pollutants that are widely found indoors is TVOC's, which could contribute to dissatisfaction of the building occupant. It could lead to distraction in students learning performance and difficulty in focusing during lecture.

\subsection{Proposed Intervention Setting for Classroom Environment}

Based on the findings from the natural condition of the existing classroom, this research proposed an intervention setting to improve the indoor environment of the classroom with application of landscaping. The plants selected in this intervention were Lily and Janet Craig. These plants are chosen in this intervention, as it is efficient in minimizing humidity and able to minimize the air pollutant in certain area.

\subsubsection{Comparative Analysis of Total Volatile Organic Compound (TVOC)}

Fig.12 shows comparison of TVOC concentration between normal condition and intervention classroom. Based on the graphs, it is observed that there was a sharp decline in the TVOC concentration when plants were placed in the classroom. Therefore, it is proven that plants could reduce the air pollutants especially TVOC inside the classroom.

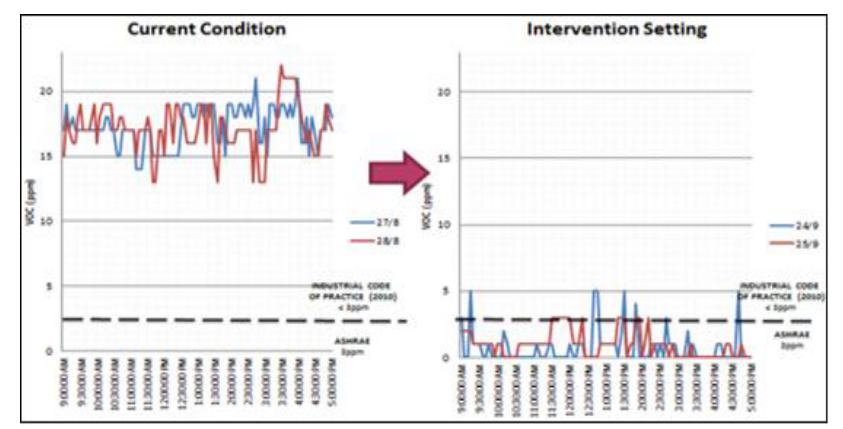

Figure 12: Comparison of TVOC concentration level between normal condition and intervention settings

\subsubsection{Comparative Analysis of Relative Humidity $(\mathrm{RH})$}

Similar to TVOC, a significant reduction was observed in RH level when plants were placed. (see Fig. 13) A significant reduction in RH level was found in sampling device located in point $\mathrm{A}$ and $\mathrm{B}$, which is near to the plants. While sampling point $\mathrm{C}$ has no significant impact based on the indoor outdoor ratio of the RH. This finding gives further evidence that the air in the classroom is not mixing well as discussed in the earlier section. However, the number of plants in the room should be considered in future to prevent further reduction of $\mathrm{RH}$ below recommended value. 


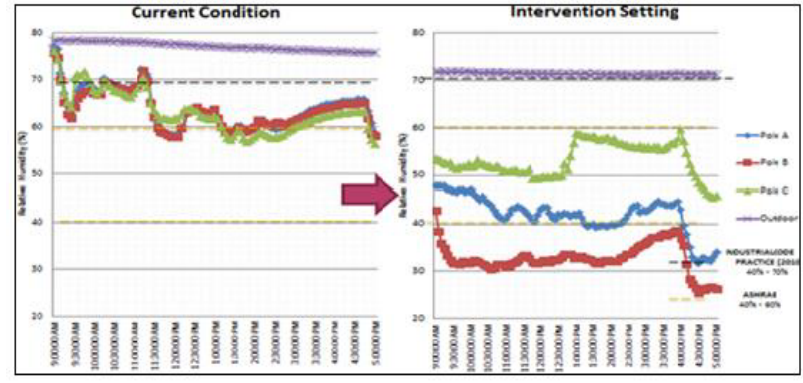

Figure 13: Comparison of Relative Humidity level between normal condition and intervention settings

\subsubsection{Summary of IEQ Measurements Comparison between Normal Condition and Intervention Settings}

Based on Table 3, can be summarized that most of the elements show reduction in the percentage. However, the temperature shows some increment due to the increase of outdoor temperature during data monitoring. Therefore, it can be assumed that most of the elements are complied with threshold limit value and guidelines when landscaping is intervened.

Table 3: Summary of IEQ Measurements In a Natural Condition Classroom and Intervention Settings

\begin{tabular}{|c|c|c|c|c|c|}
\hline \multirow{2}{*}{\multicolumn{2}{|c|}{ Element }} & \multicolumn{4}{|c|}{ Average (9am-5pm) } \\
\hline & & $\begin{array}{l}\text { Current } \\
\text { Contion }\end{array}$ & Interention & Increment $(\%)$ & Reduction (\%) \\
\hline Temperature & Outdoor & 28.3 & 33.3 & & \\
\hline (C) & Indoor & 27.9 & 29.7 & $\begin{array}{l}6.45 \% \\
\text { (difference of } 1.8 \mathrm{C} \text { C. due to } \\
\text { increase in the outdoor }\end{array}$ & \\
\hline Relative & Outdoor & 61.6 & 43.8 & & \\
\hline Humidity (\%) & Indoor & 76.4 & 71.5 & & 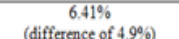 \\
\hline $\mathrm{CO}_{2}(\mathrm{ppm})$ & $\begin{array}{l}9 \mathrm{~mm}- \\
5 \mathrm{pm}\end{array}$ & 1084 & 781.89 & & $\begin{array}{c}27.87 \% \\
\text { (difference of } 302.11 \mathrm{ppm} \text { ) }\end{array}$ \\
\hline & $\begin{array}{l}8 \mathrm{pm}- \\
7 \mathrm{pm}\end{array}$ & 443.65 & 429.22 & & $\begin{array}{c}3.25 \% \\
\text { (difference of } 14.43 \mathrm{ppm} \text { ) }\end{array}$ \\
\hline VOC (ppm) & & 11.7 & 1.5 & & $\begin{array}{l}87.18 \% \\
\end{array}$ \\
\hline $\begin{array}{l}\text { Particulate } \\
\text { Manter } \\
\text { (mg min') }\end{array}$ & & 0.11 & 0.12 & $\begin{array}{c}9.09 \% \\
\text { (diffence of } 0.01 \mathrm{mgm}^{3} \text { ) }\end{array}$ & \\
\hline
\end{tabular}

\section{Conclusion and Recommendations}

General perception and level of IEQ in the classroom of Pusat Asasi Sains University of Malaya is averagely good. However, there were several major issues found when monitoring the classroom such as:

a) Irregular intensity of illuminance in the classroom referring to guideline.

b) High level of noise in the classroom exceeds the guideline.

c) High concentration of TVOC that exceeds the limits

d) Significantly higher dissatisfaction on ventilation system in the classroom.

However, based on the questionnaire, the students were neither easily interfered in terms of perceived productivity nor susceptible to any health symptoms and their performance. Moreover, there were no significant differences found on the all interferences on perceived productivity and susceptibility to health symptoms among the designated areas.

Based on the findings it is recommended that the air circulation in the classroom should be improved to remove heat as well as to increase the level of air velocity. Therefore, the exhaust fan and the air conditioning systems should be fixed and maintained. Besides that, the usage of cleaning agent that consists of high VOC should be minimized. In addition, new layout design of lighting fixtures should be installed to evenly distribute sufficient light for learning purposes. It is also recommended that periodical test (test/tutorial) to be carried out to assess students learning performance during each classroom intervention settings.

\section{References}

1. ASHRAE Standard 55 (2004).Thermal environmental conditions for human occupancy, American Society of Heating, Refrigerating and Air-Conditioning Engineers, Atlanta, GA.

2. Department of Occupational Safety \& Health (DOSH), Malaysia - National Institute of Occupational Safety \& Health (2013).

3. Fisk, W.J., 2000. Estimates of potential nationwide productivity and health benefits from better indoor environments: an update. In: Spengler, John D., Samet, Jonathan M., McCarthy, John F. (Eds.), Indoor Air Quality Handbook, Chapter 4. McGraw Hill, New York.

4. Fromme, H., Twardella, D., Dietrich, D. Heitmann, D., Schierl, R., Liebl, B., and Rüden, H., 2007. Particulate Matter in the Indoor Air of Classrooms-Exploratory Results from Munich and Surrounding Area.Atmospheric Environment, 41, pp854-866.

5. Heath, G.A. and Mendell, M.J. (2002). Do indoor environments in schools influence student performance? A review of the literaure . pp. 802-807 in Proceeding of Indoor Air 2002, Vol.1 June 30-July 5, 2002, Monterey, Calif.

6. Hill MC, Epps KK. Does physical classroom environment affect student performance, student satisfaction, and student evaluation of teaching in the college environment? Acad Educ Leadersh 2009;14(1):P15e9.

7. Kamaruzzaman, K. and Samsul, A (2013).Thermal Comfort Assessment of a Classroom in Tropical Climate Conditions. Recent Advances in Energy, Environment and Development, ISBN: 978-1-61804-157-9.

8. Mendell, M.J., Fisk, W.J., Dong, M.X., Petersen, M., Hines, C.J., Dong, M., Faulkner, D., Deddens, J.A., Ruder, A.M., Sullivan, D.A., Boeniger, M.F., 2002. Indoor particles and symptoms among office workers: results from a double-blind cross-over study. Epidemiology 13, 296-304.

9. Ministry of Education (MOE),2013. Statistic.[online] Available at: 
http://www.moe.gov.my/[Accessed 10 June 2014].

10. NIOSH, 2013. Centre for Disease and Control Prevention [online] (June 2013) Available at http://www.cdc.gov/niosh/topics/indoorenv/[Acc essed 12 November 2013].

11. Turunen, M., Toyinbo, O., Putus, T., Nevalainen, A., Shaughnessy, R., \& HaverinenShaughnessy, U. Indoor environmental quality in school buildings, and the health and wellbeing of students. International Journal of Hygiene and Environmental Health.

12. Wood, R., Orwell, R., Tarran, J., Torpy, F., and Burchett, M.:2006, 'The Potted- Plant Microcosm Substantially Reduces Indoor Air VOC Pollution: II. Laboratory Study', Volume 177, Issue 1-4 , pp 59-80 